\title{
EVALUASI DAN IMPLIKASI KEBIJAKAN PEMBERANTASAN KEJAHATAN PERIKANAN DI INDONESIA 2014-2018
}

\author{
Muhamad Karim \\ Program Studi Agribisnis, Universitas Trilogi Jakarta \\ Jl. TMP Kallibata No 1 Jakarta Selatan \\ E-mail: karimlaode1971@ trilogi.ac.id
}

\begin{abstract}
ABSTRAK
Kejahatan perikanan telah berlangsung sejak tahun 1970-an di Indonesia. Studi ini bertujuan (i) menganalisis kebijakan pemberantasan kejahatan perikanan di Indonesia; (ii) menganalisis dampak kebijakan pemberantasan kejahatan perikanan terhadap keberlanjutan sumber daya perikanan dan kesejahteraan nelayan, dan (iii) memberikan rumusan rekomendasi bagi pengelolaan sumber daya perikanan yang berkelanjutan dan mensejahterakan seluruh rakyat. Penelitian ini bersifat deskriptif-kualitatif dengan menggunakan data-data sekunder. Data-data tersebut diperoleh dari instansi terkait Badan Pusat Statistika, publikasi Kementerian Kelautan dan Perikanan Republik Indonesia, Bank Indonesia dan dokumen hasil penelitian relevan. Penelitian ini menggunakan metode deskriptif analisis dari kebijakan publik. Hasilnya disajikan dalam bentuk tabel, diagram, histogram, dan persentase yang kemudian diinterpretasikan. Penelitian ini menyimpulkan bahwa kebijakan pemberantasan kejahatan perikanan di Indonesia selama kurun waktu 2014-2018 belum berjalan secara optimal karena implementasi pada tataran nasional masih menimbulkan resistensi seperti dalam kasus pelarangan cantrang. Kebijakan ini juga berdampak positif terhadap keberlanjutan sumber daya ikan di Indonesia dan kesejahteraan nelayan. Meskipun, kejahatan perikanan masih sering terjadi seperti penangkapan ikan oleh kapal asing ilegal. Pasca 2019, kebijakan ini harus tetap dilanjutkan agar melindungi sumber daya ikan dan menjamin kedaulatan Indonesia atas sumber daya lautnya. Hasil studi ini merekomendasikan bahwa penanganan kasus kejahatan perikanan tidak selamanya dengan mekanisme pengadilan pidana semata, melainkan bisa juga dapat dilakukan melalui meknaisme non pengadilan yaitu mekanisme keadilan restoratif (restorative justice).
\end{abstract}

Kata kunci: IUU; Keadilan Restoratif; Keberlanjutan; Kejahatan Perikanan.

\section{EVALUATION AND ITS IMPLICATION OF FISHERIES CRIMES ERADICATION POLICY IN INDONESIA DURING 2014-2018}

\begin{abstract}
Fisheries crimes have been taking place since the 1970s in Indonesia. This study aims to (i) analyze fisheries crime eradication policies in Indonesia; (ii) analyze the impact of fisheries crime eradication policies on the sustainability of fisheries resources and fishermen's welfare, and (iii) provide recommendations for the sustainable management fisheries resources that will prosper all the people. This research is descriptive-qualitative by using secondary data. The data was obtained from relevant agencies of the Statistics Indonesia, the publication of the Ministry of Marine Affairs and Fisheries Republic of Indonesia, Bank Indonesia and relevant research findings documents. This research used descriptive analysis method included public policy analysis. The results are presented in tables, diagrams, histograms, and percentages which are then interpreted. This study concludes that the policy to eradicate fisheries crime in Indonesia during the period 2014-2018 had not been run optimally because the implementation at the national level still raises resistance such as the case of prohibiting cantrang. This policy also has a positive impact on the sustainability of fish resources in Indonesia and fishermen welfare. Although, fisheries crimes are still frequently occured such as fishing conducted by illegal foreign vessels. Post 2019 , this policy must be continued in order to protect fish resources and guarantee Indonesia's sovereignty over its marine resources. The results of this study recommended the handling of fishery crime cases are not always treated through court mechanism, but can also be treadted through a non-court mechanism namely restorative justice.
\end{abstract}

Keywords: IUU; Restorative Justice; Sustainability; Fisheries Crime.

\section{PENDAHULUAN}

Studi yang dilakukan Agnew et al., (2009) menyatakan bahwa aktivitas kejahatan penangkapan ikan secara ilegal, tidak dilaporkan dan tidak diatur (illegal, unreported and unregulated fishing - IUU fisihing) berkontribusi terhadap eksploitasi stok sumber daya ikan dan menghambat pemulihan populasi serta ekosistemnya. Hasil studinya memperkirakan bahwa nilai kerugian akibat penangkapan ikan secara ilegal dan tidak dilaporkan di seluruh dunia mencapai 11 juta dan 26 juta ton dengan nilai sebesar USD 10 miliar dan USD 23 miliar per tahun. Kerajaan Inggris telah merasakan dampak aktivitas kejahatan penangkapan ikan yang disebabkan penggunaan trawl dasar. Studi Thurstan et al., (2010) menyebutkan bahwa dalam rentang waktu 118 tahun dari 1889-2007 terjadi tingkat eksploitasi sumber daya ikan hingga $88 \%$ dan perubahan pendaratan per unit daya tangkap (landings per unit of fishing power) hingga 94\% atau 17 kali lipatnya selama kurun waktu tersebut, sejak dimulainya industrialisasi perikanan pada abad 19 . Indonesia sendiri akibat kejahatan perikanan ilegal menelan kerugian diperkirakan sebesar USD 20 juta per tahun (Kasim \& Widagdo, 2019).

Kejahatan IUU fishing dalam penilaian organisasi United Nations Office on Drugs and Crime (UNDOC) yang berpusat di Vienna mengkategorikannya sebagai kejahatan internasional karena bukan hanya soal ikan, melainkan juga kapal ilegal yang dipergunakan untuk menyelundupkan 
obat terlarang, perdagangan senjata dan penyaluran imirgan gelap dengan berkedok menangkap ikan (UNDOC, 2011). Telesetsky (2015) menyebut kejahatan perikanan sebagai "kejahatan transnasional yang serius" (transnational serious crime). Oleh karena itu, para pihak yang mempersoalkan pemberantasan kejahatan IUU fishing sejak tahun 2014-2018 seyogyanya patut dipertanyakan ada apa dibalik protes tersebut. Puspoayu et al., (2019) juga menyepakati bahwa IUU fishing termasuk sebagai kejahatan kriminal transnasional (Transnational Organized Crime/TOC).

Di Indonesia, aktivitas IUU fishing sudah berlangsung lebih dari tiga dekade semenjak Indonesia menggulirkan kebijakan modernisasi perikanan tahun 1970-an. Namun, kejahatan IUU fishing tidak pernah berhenti dan makin merajalela di Indonesia. Pada masa pemerintahan Orde Baru dikeluarkan Keputusan Presiden (Keppres) No. 39 Tahun 1980 tentang Pelarangan Alat Tangkap Pukat Harimau (Trawl) di Perairan Indonesia. Pertimbangan dikeluarkannya Keppres tersebut adalah (i) pelaksanaan pembinaan kelestarian sumberdaya ikan dasar; (ii) mendorong peningkatan produksi yang dihasilkan oleh para nelayan tradisional; dan (iii) menghindari terjadinya ketegangan-ketegangan sosial. Pelarangan alat tangkap trawl ini dilakukan secara bertahap selama setahun yaitu dari tanggal 1 Juli 1980 sampai 1 Juli 1981 sehingga jumlah kapalnya berkurang dan tinggal 1000 unit. Pelaksanaan Keppres tersebut berlaku di pulau Sumatera, Jawa dan Bali. Meskipun kebijakan ini sudah dikeluarkan, namun dalam praktiknya aktivitas IUU fishing masih tetap berlangsung.

Tindakan penanganan IUU fishing secara tegas dan tanpa kompromi baru dilaksanakan mulai tahun 2014 melalui Peraturan Presiden (Perpres No. 115 Tahun 2015) tentang Satuan Tugas Pemberantasan Penangkapan Ikan secara Ilegal (Illegal Fsihing) dan peraturan-peraturan menteri kelautan dan perikanan sebagaimana disajikan dalam Tabel 1. Penanganan ini dilakukan karena Presiden Jokowi telah berkomitmen menjadikan Indonesia sebagai poros maritim dunia dan salah satu prasyaratnya yaitu memosisikan Indonesia sebagai negara yang memanfaatkan laut secara mandiri dan bertanggungjawab. Hal ini penting agar sektor kelautan dan perikanan sebagai salah satu prioritas pembangunan Indonesia mampu mewujudkan capaian kedaulatan pangan (Pudjiastuti, 2016).

Praktik IUU fishing di Indonesia telah merugikan negara melalui kegiatan alih muatan (transhipment) di tengah laut yang diduga menggelapkan pajak. Jika kejahatan ini tidak ditertibkan pemerintah, maka akan menguras kekayaan sumber daya ikan di perairan Indonesia dan Zona Ekonomi Eksklusif Indonesia (ZEEI). Meskipun demikian, ada berbagai pihak yang meragukan pemberantasan kejahatan perikanan yang dilakukan sejak tahun 2014-2018. Keraguan ini diduga akibat adanya oknum yang bisnisnya dalam bidang perikanan berkaitan dengan perikanan ilegal maupun eks-kapal ikan asing yang dilarang beroperasi di Indonesia sehingga berupaya mendelegitimasi kebijakan pemerintah yang sudah diterapkan. Padahal di awal kebijakan ini telah berdampak terhadap negara yang selama ini mencuri ikan di perairan Indonsia dan ZEEI seperti Thailand. World Bank (2017) mencatat bahwa kontribusi sektor perikanan Thailand terhadap Produk Domestik Bruto (PDB)-nya mengalami penurunan drastis akibat kebijakan pemberantasan kejahatan IUU fishing di Indonesia selama periode 2014-2015. Pada tahun 2014 kontribusi perikanan terhadap PDB riil Thailand sebesar $-13.3 \%$ sedangkan tahun 2015 sebesar $-2.3 \%$. Nilai kontribusi perikanan terhadap PDB-nya kembali bernilai positif pada tahun 2016 sebesar $0.8 \%$. Disamping itu, praktik IUU fishing juga berdampak terhadap pengelolaan perikanan berkelanjutan dan menghasilkan kerugian ekonomi. Salah satu bentuknya adalah penyalahgunaan perizinan dengan mark down ukuran kapal penangkapan ikan. Penelitian Firdaus et al., (2017) menemukan bahwa praktik "mark down" tahun 2015 mengakibatkan deplesi sumber daya ikan di perairan Indonesia sebesar Rp 9.83 triliun. Varkey et al., (2010) menyebutkan bahwa penangkapan ikan ilegal dan tidak dilaporkan dari jenis ikan karang, tuna, teri, hiu, teripang dan lobster di Raja Ampat tahun 2006 menunjukkan bahwa melebihi tangkapan yang dilaporkan hingga 40 ribu ton yang diperkirakan mencapai USD 40 juta. Tindakan ini mengancam keberlanjutan perikanan dan mata pencaharian masyarakat di wilayah itu.

Penelitian ini dimaksudkan untuk mengevaluasi dan menganalisis dampak kebijakan pemberantasan kejahatan perikanan khususnya IUU fishing di Indonesia. Hasil analisis ini diharapkan akan memberikan cara pandang yang obyektif dan ilmiah tentang pentingnya memberantas kejahatan perikanan di Indonesia yang merugikan masyarakat dan negara. Tujuan penelitian ini adalah (i) menganalisis kebijakan pemberantasan kejahatan perikanan di Indonesia; (ii) menganalisis dampak kebijakan pemberantasan kejahatan perikanan terhadap keberlanjutan sumber daya perikanan dan kesejahteraan nelayan; dan (ii) memberikan rumusan rekomendasi bagi pengelolaan sumber daya perikanan yang berkelanjutan dan mensejahterakan seluruh rakyat.

\section{METODE}

Penelitian ini dilaksanakan di Jakarta pada bulan April sampai dengan Juni 2017. Penelitian ini berbentuk studi pustaka yaitu menggunakan pustaka dan data-data sekunder yang berasal dari instansi terkait dan lembaga-lembaga yang kredibel. Studi kepustakaan merupakan kajian teoritis, referensi serta literatur ilmiah lainnya yang berkaitan dengan budaya, nilai dan norma yang berkembang pada 
situasi sosial yang diteliti (Sugiyono, 2012). Data yang digunakan dalam penelitian ini adalah data sekunder yang diperoleh dari berberbagai instansi pemerintah anrara lain: Badan Pusat Statistika (BPS), publikasi Kementerian Kelautan dan Perikanan (KKP) Republik Indonesia, Bank Indonesia (BI) dan data-data hasil penelitiannya lainnya yang relevan bersumber dari jurnal. Hal ini dimaksudkan untuk mendukung dan memperkuat analisis dalam penelitian ini. Metode analisis yang digunakan dalam penelitian ini adalah bersifat deskriptif analitis untuk menganalisis kebijakan publik terkait evaluasi dan implikasi kebijakan pemberantasan kejahatan perikanan periode 2014-2018. Menurut Sugiyono (2012) metode deskriptif analitis adalah suatu metode yang digunakan untuk menggambarkan atau menganalisis suatu hasil penelitian tetapi tidak digunakan untuk membuat kesimpulan yang lebih luas. Hasil analisis disajikan dalam bentuk tabel, diagram, histogram, dan persentase yang selanjutnya diinterpretasikan.

Penelitian ini juga merupakan suatu bentuk riset kebijakan publik. Dunn (2013) menyatakan bahwa kebijakan publik (Public Policy) adalah pedoman yang mengandung nilai-nilai dan normanorma yang memiliki kewenangan untuk mendukung tindakan-tindakan pemerintah dalam wilayah yurisdiksinya. Ditambahkan bahwa analisis kebijakan publik yaitu suatu disiplin ilmu sosial, terapan, yang menggunakan berbagai macam metode penelitian dan argumen untuk menghasilkan dan mentransformasikan informasi yang relevan dengan kebijakan yang digunakan dalam lingkungan politik tertentu untuk memecahkan permasalahan kebijakan. Analisis kebijakan publik bertujuan memberikan rekomendasi untuk membantu para pembuat kebijakan agar dapat memecahkan masalah-masalah publik. Tiga bentuk utama analisis kebijakan publik (Dunn, 2013) :

1. Analisis kebijakan prospektif. yaitu memproduksi dan mentransformasikan informasi sebelum aksi kebijakan dimulai dan diimplementasikan. Analisis kebijakan ini merupakan alat untuk mensintesakan informasi agar digunakan untuk merumuskan alternatif dan preferensi kebijakan yang dinyatakan secara komparatif, diramalkan dalam bahasa kuantitatif dan kualitatif sebagai landasan atau penuntun dalam pengambilan keputusan suatu kebijakan.
2. Analisis kebijakan retrospektif adalah menciptakan dan mentransformasikan informasi sesudah aksi kebijakan dilaksanakan. Tipe analisisnya yakni berorientasi pada disiplin, berorientasi pada masalah dan berorientasi pada aplikasi yang masing-masing memiliki kelebihan dan kelemahan.

3. Analisis kebijakan yang terintegrasi yaitu mengkombinasikan gaya operasi praktisi yang menekankan penciptaan dan transformasi informasi sebelum dan sesudah tindakan kebijakan dikeluarkan. Dalam analisis kebijakan terintegrasi tidak hanya mengharuskan analis mengkaitkan tahap penyelidikan retrospektif dan perspektif, tetapi juga menuntut analis untuk menghasilkan dan mentransformasikan informasi setiap saat.

Dalam konteks penelitian ini menggunakan bentuk analisis yang terintegrasi yaitu menganalisis kebijakan pemberantasan kejahatan perikanan dan dampaknya setelah diimpelemntasikan.

\section{HASIL DAN PEMBAHASAN}

\section{Review Kebijakan Era Pemerintahan Jokowi 2014-2018}

Pemerintahan Presiden Jokowi pertama kali dilantik sebagai Presiden tahun 2014 mendeklarasikan bahwa akan menjadikan Indonesia sebagai Poros Maritim Dunia. KKP mewujudkan visi tersebut dengan membangun tiga pilar pembangunan kelautan dan perikanan yaitu kemakmuran (prosperity), keberlanjutan (sustainability) dan kedaulatan (sovereignty) yang harus berjalan seimbang untuk mewujudkan poros maritim dunia (Pudjiastuti, 2016). KKP telah meluncurkan beberapa kebijakan vital dan strategis, diantaranya yaitu kebijakan pemberantasan kejahatan IUU fishing yang sudah puluhan tahun melanda Indonesia, meskipun dalam kenyatannya belum dapat dituntaskan. Kejahatan ini diperkirakan merugikan negara hingga 300 triliunan rupiah setiap tahunnya (Pudjiastuti, 2016). Berbeda dengan perikaraan Kasim \& Widagdo (2019) menyebutkan kerugian akibat kejahatan perikanan mencapai USD 20 miliar per tahun atau setara Rp 30 triliun dengan asumsi 1 USD sebesar Rp 15.000. Berbagai kebijakan yang telah dikeluarkan KKP untuk memberantas kejahatan IUU Fishing sejak tahun 2014 disajikan dalam Tabel 1.

Tabel 1 Kebijakan KKP 2014-2018 dalam memberantas IUU Fishing.

\begin{tabular}{|c|c|c|c|}
\hline No. & Permasalahan & Kebijakan & Jenis Pengaturan \\
\hline 1 & $\begin{array}{l}\text { Masifnya kejahatan } \\
\text { perikanan ilegal di } \\
\text { Indonesia }\end{array}$ & $\begin{array}{l}\text { Peraturan } r \text { Presiden } \\
\text { (Perpres No. 115 Tahun } \\
2015) \text { tentang Satuan } \\
\text { Tugas Pemberantasan } \\
\text { Penangkapan Ikan secara } \\
\text { Ilegal (Illegal Fishing) }\end{array}$ & $\begin{array}{l}\text { Mengembangkan dan melaksanakan } \\
\text { operasi penegakan hukum dalam upaya } \\
\text { pemberantasan penangkapan ikan secara } \\
\text { ilegal di wilayah laut yurisdiksi Indonesia } \\
\text { secara efektif dan efisien termasuk yang } \\
\text { tidak dilaporkan (unreported). }\end{array}$ \\
\hline
\end{tabular}




\begin{tabular}{|c|c|c|c|}
\hline 2. & $\begin{array}{l}\text { Penurunan populasi, } \\
\text { Lobster (Panulirus spp.), } \\
\text { Kepiting (Scylla spp.) dan } \\
\text { Rajungan (Portunus } \\
\text { pelagicus spp.) }\end{array}$ & $\begin{array}{l}\text { Peraturan Kementrian } \\
\text { Kelautan dan Perikanan } \\
\text { (Permen KP) No. } 1 \text { Tahun } \\
2015 \text { tentang Larangan } \\
\text { Penangkapan Lobster, } \\
\text { Kepiting dan Rajungan }\end{array}$ & $\begin{array}{l}\text { Larangan melakukan penangkapan } \\
\text { lobster, kepting dan rajungan dalam } \\
\text { kondisi bertelur (Pasal 2). Penangkapan } \\
\text { yang diperbolehkan (Pasal 3): } \\
\text { - Lobster (Panulirus spp.) dengan } \\
\text { ukuran panjang karapas >8 cm (di } \\
\text { atas delapan sentimeter); } \\
\text { - Kepiting (Scylla spp.) dengan ukuran } \\
\text { lebar karapas }>15 \mathrm{~cm} \text { (di atas lima } \\
\text { belas sentimeter); dan } \\
\text { Rajungan (Portunus pelagicus spp.) } \\
\text { dengan ukuran lebar karapas }>10 \mathrm{~cm} \\
\text { (di atas sepuluh sentimeter). }\end{array}$ \\
\hline 3. & $\begin{array}{l}\text { Ancaman kelestarian } \\
\text { sumber daya ikan atas } \\
\text { penggunaan alat tangkap } \\
\text { pukat hela dan pukat tarik }\end{array}$ & $\begin{array}{l}\text { Permen KP No. } 2 \text { Tahun } \\
2015 \text { tentang Larangan } \\
\text { Penggunaan Alat } \\
\text { Penangkapan Ikan Pukat } \\
\text { Hela (Trawls) dan Pukat } \\
\text { Tarik (Seine Nets) di } \\
\text { wilayah pengelolaan } \\
\text { perikanan negara Republik } \\
\text { Indonesia }\end{array}$ & $\begin{array}{l}\text { Setiap orang dilarang menggunakan alat } \\
\text { penangkapan ikan pukat hela (trawls) dan } \\
\text { alat penangkapan ikan pukat tarik (seine } \\
\text { nets) di seluruh Wilayah Pengelolaan } \\
\text { Perikanan Negara Republik Indonesia } \\
\text { (WPPNRI) (Pasal 2) }\end{array}$ \\
\hline 4. & $\begin{array}{lr}\text { Pengaturan } & \text { kembali } \\
\text { jalur-jalur } & \text { penangkapan } \\
\text { ikan } & \end{array}$ & $\begin{array}{l}\text { Permen KP No. } 71 \text { Tahun } \\
2016 \text { tentang Jalur } \\
\text { Penangkapan Ikan dan } \\
\text { Penempatan } \\
\text { Penangkapan Ikan di } \\
\text { Wilayah } \\
\text { Perikanan Negara Republik } \\
\text { Indonesia (WPPNRI) }\end{array}$ & 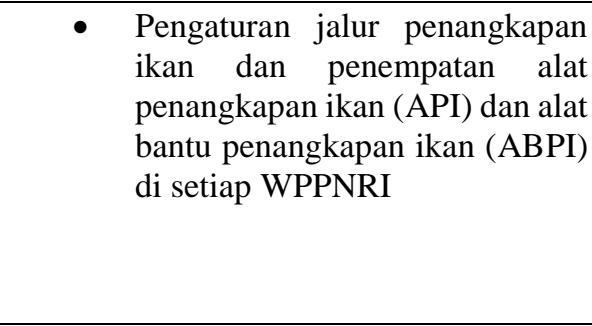 \\
\hline 5. & $\begin{array}{l}\text { IUU fishing dan kegiatan } \\
\text { alih muatan } \\
\text { (transhipment) di tengah } \\
\text { laut yang merugikan } \\
\text { negara }\end{array}$ & $\begin{array}{l}\text { Permen KP. No } 57 \text { Tahun } \\
2014 \text { tentang Perubahan } \\
\text { kedua atas Permen KP No. } \\
30 \text { Tahun } 2012 \text { tentang } \\
\text { Usaha Perikanan Tangkap } \\
\text { di wilayah pengelolaan } \\
\text { perikanan Negara Republik } \\
\text { Indonesia }\end{array}$ & 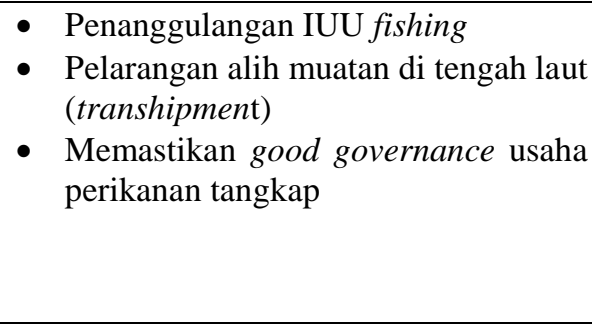 \\
\hline 6. & $\begin{array}{l}\text { IUU fishing (Perizinan } \\
\text { usaha perikanan tangkap) }\end{array}$ & $\begin{array}{l}\text { Permen KP. No } 10 \text { Tahun } \\
2015 \text { tentang Perubahan } \\
\text { atas Permen KP No. 56 } \\
\text { Tahun 2014 tentang } \\
\text { Penghentian Sementara } \\
\text { (Moratorium) Perizinan } \\
\text { Usaha Perikanan Tangkap } \\
\text { di Wilayah Pengelolaan } \\
\text { Perikanan Negara Republik } \\
\text { Indonesia }\end{array}$ & $\begin{array}{l}\text { - Penghentian sementara perizinan } \\
\text { usaha perikanan tangkap } \\
\text { sebagaimana dimaksud dalam Pasal } 1 \\
\text { berlaku sampai dengan tanggal } 31 \\
\text { Oktober 2015 (termasuk Moratorium) } \\
\text { - Memastikan good governance usaha } \\
\text { perikanan tangkap }\end{array}$ \\
\hline 7. & $\begin{array}{l}\text { IUU fishing (Perizinan } \\
\text { usaha perikanan tangkap) }\end{array}$ & $\begin{array}{l}\text { Permen KP No. } 15 \text { Tahun } \\
2016 \text { tentang Kapal } \\
\text { Pengangkut Ikan Hidup }\end{array}$ & $\begin{array}{l}\text { - Kewajiban setiap orang memiliki } \\
\text { Surat Izin Kapal Pengangkut Ikan } \\
\text { (SIKPI) yang melakukan usaha } \\
\text { pengangkutan ikan hidup di } \\
\text { WPPNRI } \\
\text { - } \text { Pembatasan kapal pengangkut ikan } \\
\text { hidup dengan ukuran: } \\
\text { - } 300 \text { GT dari hasil penangkapan } \\
\text { ikan } \\
\text { - 500 GT dari hasil pembudiayaan } \\
\text { ikan } \\
\text { SIKPI terdiri: }\end{array}$ \\
\hline
\end{tabular}




\begin{tabular}{|c|c|c|c|}
\hline & & & 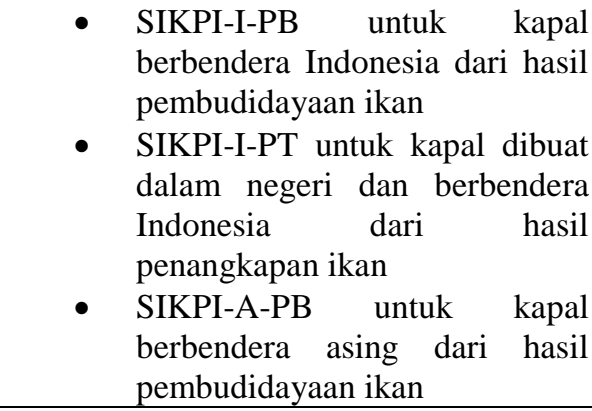 \\
\hline 8. & $\begin{array}{l}\text { Pembenahan Tata Kelola } \\
\text { Kapal Angkut Ikan Hidup }\end{array}$ & $\begin{array}{l}\text { Permen KP No. } 49 \text { Tahun } \\
2014 \text { tentang Usaha } \\
\text { Pembudidayaan Ikan }\end{array}$ & 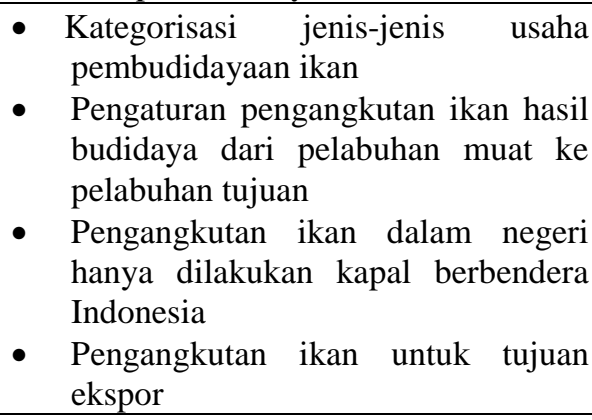 \\
\hline 9. & $\begin{array}{l}\text { Kasus Hak Asasi Manusia } \\
\text { (HAM) }\end{array}$ & $\begin{array}{l}\text { Permen KP No. } 35 \text { Tahun } \\
2015 \text { tentang Sistem dan } \\
\text { Sertifikasi Hak Azasi } \\
\text { Manusia pada } \\
\text { Perikanan }\end{array}$ & 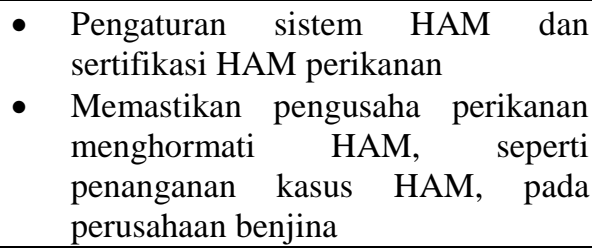 \\
\hline
\end{tabular}

Kebijakan pemerintah salah satunya adalah untuk memberantas kejahatan perikanan seperti penangkapan ilegal, yang tidak dilaporkan (unreported) dan tidak diatur (unregulated). Hal ini tercermin dari berbagai peraturan Presiden dan Permen KP yang lahir semenjak tahun 2014. Dasar pertimbangan lahirnya Peraturan Presiden dan Permen KP tersebut adalah kegiatan IUU fishing telah menyebabkan kerugian negara dan sebagian wilayah pengelolaan perikanan Republik Indonesia (WPP NRI) mengalami tangkap lebih (over exploitation). Sesungguhnya Indonesia sejak tahun 2004 telah menerbitkan Undang-Undang Perikanan No. 31 Tahun 2004 dan revisinya Undang-Undang Perikanan No 45 Tahun 2009 yang menjadi payung hukum untuk menindak kejahatan perikanan. Kedua perundangan tersebut mengandung ketentuan penenggelaman kapal yang terbukti melakukan penangkapan ikan tanpa izin. Namun selama kurun waktu lima tahun sejak berlakunya aturan tersebut belum berjalan optimal untuk menegakkan hukum di wilayah perairan dan ZEEI Indonesia. Permasalahannya adalah kurangnya koordinasi antar instansi terkait dengan kewenangannya masingmasing seperti Tentara Nasional Indonesia Angkatan Laut (TNI AL), Polisi Air, Kapal Pengawas Perikanan, Kementerian Kelautan dan Perikanan dan Kesatuan Penjaga Laut dan Pantai, Kementerian Perhubungan. Akibatnya dalam praktiknya sering terjadi tumpang tindih kewenangan dalam penegakan hukum yang mengakibatkan ketidakpastian hukum, inefisiensi anggaran dan konflik antar instansi pemerintah.
Secara historis, kejahatan perikanan di Indonesia ini telah berlangsung hampir lima dekade sejak tahun 1970-an dan pemberantasannya tidak pernah dilakukan secara totalitas dan cenderung parsial. Penyebabnya, adalah aktivitas IUU fishing tersebut juga melibatkan oknum aparat, politisi, pengusaha domestik dan birokrat yang mencari rente ekonomi lewat komisi/setoran para pelakunya.

Sejak tahun 2014, pemerintah mulai menghentikan total aktivitas IUU fishing secara tegas dengan melakukan penangkapan dan penenggelaman kapal ikan asing. Kebijakan ini perkuat oleh Perpres No. 115 Tahun 2015 tentang Satuan Tugas Pemberantasan Penangkapan Ikan secara Ilegal (Illegal Fishing) sebagai bentuk dukungan penuh dari Presiden Republik Indonesia dan seluruh komponen penegak hukum yaitu: Kementerian Kelautan dan Perikanan, TNI-AL, Kepolisian Negara Republik Indonesia, Kejaksaan Agung Republik Indonesia, Badan Keamanan Laut, Satuan Kerja Khusus Pelaksana Kegiatan Usaha Hulu Minyak dan Gas Bumi, PT Pertamina, dan institusi terkait lainnya. Namun demikian, kebijakan ini juga mendapatkan resistensi dan penolakan dari oknum politisi di parlemen, akademisi, organisasi sosial kemasyarakatan, dan kalangan korporasi yang mengklaim mengalami kesulitan untuk bahan baku industri perikanan. Diduga mengandung kepentingan ekonomi politik yang menyertainya karena berbentuk konspirasi bisnis dan politik dengan para pelaku IUU fishing. Meskipun dugaan ini sukar dibuktikan secara empirik. Namun demikian, munculnya lobi-lobi politik di parlemen, pernyataan sikap ke Presiden 
maupun Wakil Presiden, tekanan dari elit politik, gerakan massa dengan memanfaatkan nelayan Pantai Utara Jawa (Pantura) yang diklaim dirugikan dan mengalami kemiskinan berlangsung sistemik kurun waktu 2017-2018 adalah buktinya. Fenomena ini mengindikasikan adanya gerakan politik yang hendak menghentikan kebijakan tersebut. Kebijakan ini akan memberikan respon dan hasil yang berbeda pada tataran implementasi jika pemerintah dalam proses menyusunnya sesuai tatakelola pemerintahan yang bersifat partisipatif dengan melibatkan komponen masyarakat seperti organisasi sosial kemasyarakatan, gerakan masyarakat sipil, dan organisasi nelayan. Dengan demikian resistensi dan penolakan terhadap kebijakan tersebut relatif kecil kemungkinannya karena aspirasi masyarakat telah terakomodasi.

Bennet et al., (2015) menyatakan bahwa aktivitas IUU fishing ini dikategorikan sebagai perampasan ruang laut dan sumber dayanya (Ocean Grabbing), sehingga tindakan pemberantasannya mesti dilakukan secara sistemik. Salah satu kebijakan pemberantasan kejahatan perikanan yang yng dilakukan pemerintah dan menimbulkan protes adalah larangan alih muatan di tengah laut (transhipment). Larangan ini telah diatur dalam Permen KP No. 57 Tahun 2014 tentang Perubahan Kedua atas Permen KP No. 30 Tahun 2012 yang mengatur Usaha Perikanan Tangkap di WPPNRI. Pelarangan (transhipment) ini bukan hanya dilakukan di Indonesia, tetapi Organisasi Pengelolaan Perikanan Regional Regional (Fisheries Management Organizations/RFMOs) yang bertanggung jawab mengelola perikanan laut lepas di dunia sudah mencoba menerapkannya tapi masih bersifat parsial. Penelitian Ewell et al., (2017) menyimpulkan bahwa hasil evaluasi peraturan alih muatan terhadap 17 RFMOs ditemukan penerapan ketentuan pengiriman ikan hasil tangkapan di laut lepas makin ketat sejak tahun 1990-an. Semua RFMOs memang belum melarang secara total alih muatan di tengah laut yang berdampak secara ekologi dan sosial, namun sudah ada yang menerapkannya secara parsial seperti Organisasi Perikanan Atlantik Tenggara (South East Atlantic Fisheries Organization/SEAFO). Riset ini merekomendasikan agar semua RFMO melarang total alih muatan agar mencegah IUU fishing, perdagangan manusia dan kerja paksa di laut lepas. Maknanya, kebijakan larangan alih muatan di tengah laut ini sebagai langkah efektif untuk menangani kejahatan perikanan. Dalam penelitian Widodo \& Suryanto (2015) juga menyimpulkan bahwa penerapan Permen KP No. 57 Tahun 2014 yang melarang alih muatan di tengah laut terhadap kapal pukat cincin pelagis besar di WPP NRI 716-717 yang berbasis di Bitung dinilai efektif dalam mencegah kejahatan perikanan walaupun berdampak positif dan negatif. Dampak positifnya, ikan tuna yang ditangkap pasca penerapan aturan selama 8 bulan ukurannya bertambah. Sementara, dampak negatifnya, selama penerapan kebijakan pasokan bahan baku industri pengolahan ikan tuna di Bitung berkurang \pm 40.968 ton. Namun, sejak tahun 2015 sejumlah 10 unit kapal cincin dioperasikan dengan modifikasi palkanya agar tidak akan melakukan alih muatan. Penelitian Ewell et al., (2017) menyatakan bahwa alih muatan di tengah laut sudah umum dilakukan dalam kegiatan industri perikanan yang menangkap di laut lepas karena efisiensi penggunaan bahan bakar. Namun, alih muatan di tengah laut memiliki kelemahan yaitu tingginya aktivitas IUU fishing yang mencapai kerugian secara global US \$ 10 miliar sampai US \$ 23.5 per tahun dan kapal penangkap ikannya dapat menghindari pemantauan dan penegakkan hukum.

Penelitian Hikmayani et al., (2015) di Bitung dan DKI Jakarta juga menyimpulkan bahwa kebijakan pelarangan alih muatan efektif mengurangi illegal fishing. Namun kebijakan ini tidak efektif untuk meningkatkan kinerja usaha penangkapan skala besar dan cukup efektif bagi peningkatan kinerja usaha penangkapan ikan skala kecil. Oleh karena itu, diperlukan monitoring dan pengawasan yang efektif dalam penerapannya (Arthatiani \& Apriliani, 2015). Hal ini disebabkan pasca pelarangan alih muatan eks kapal ikan asing terjadi penurunan 5\% volume produksi ikan tuna di DKI Jakarta. Akibatnya, volume ekspor tuna segar menurun $24 \%$ dan volume ekspor tuna beku meningkat 8\%. Penelitian Kondo et al., (2019) menyatakan bahwa secara makro ekonomi akibat kebijakan ini dalam periode 2015-2017 mengakibatkan terjadinya pertumbuhan negatif dalam sektor perikanan di Kota Bitung, tetapi terjadi peningkatan rata-rata nilai tukar nelayan dan rasio nelayan/kru lokal terhadap ABK/kru asing. Dari fakta-fakta ilmiah di atas menunjukkan bahwa kebijakan larangan alih muatan memberikan dampak positif dan negatif sehingga diperlukan langkah antisipasi yang tepat dalam penerapannya agar memberikan manfaat bagi kinerja usaha perikanan.

\section{Dampak Pemberantasan Kejahatan Perikanan}

Kebijakan pemberantasan kejahatan perikanan berdampak terhadap (i) stok sumber daya ikan; (ii) secara ekonomi yang meliputi kapasitas terpasang sumber daya ikan, necara perdagangan dan PDB sektor perikanan, penerimaan negara bukan pajak (PNBP), pajak perikanan dan nilai tukar nelayan serta; (ii) sosial. Aspek sosial yang dimaksud ialah berkurangnya intensitas konflik dalam memperebutkan wilayah tangkap antara nelayan kecil dan kapal perikanan ilegal yang mencuri ikan di perairan dan ZEEI atau antara sesama nelayan akibat perbedaan teknologi penangkapan yang digunakan.

\section{Stok Sumber Daya Ikan}

Sejak penerapan tata kelola perikanan berkelanjutan mulai 2014, potensi sumber daya ikan (SDI) Indonesia meningkat dari 7.3 juta ton tahun 2013 per tahun menjadi 12.54 juta ton per tahun 2016 (Kepmen KP. No 47 Tahun 2016). Hal ini 
membuktikan bahwa kebijakan pemerintah memberantas kejahatan perikanan berimplikasi terhadap perbaikan potensi maksimum sumber daya ikan lestari (maximum sustainability yield/MSY) di Indonesia. Hal ini memiliki substansi yang sama dengan kajian Cabral et al., (2018) yang menyatakan bahwa kebijakan Indonesia memberantas perikanan ilegal telah mengurangi upaya total penangkapan ikan hingga $25 \%$ tanpa menimbulkan kerugian jangka pendek bagi ekonomi perikanan lokal. Selanjutnya, dinyatakan bahwa jika dibandingkan dengan model pengelolaan reformasi perikanan yang membutuhkan pengurangan tangkapan hingga $15 \%$ dan pengurangan laba $16 \%$, maka pendekatan pembatasan IUU fishing berpotensi meningkatkan tangkapan $14 \%$ dan laba $12 \%$. Hal ini memberikan keuntungan dan dapat dikembangkan diberbagai wilayah di dunia yang lain. Hal ini juga dapat dibuktikan secara empiris akibat pelarangan IUU fishing, stok sumber daya ikan di berbagai wilayah mengalami perbaikan. Penelitian KKP (2016) melaporkan bahwa prosentasi peningkatan stok sumber daya ikan di perairan Indonesia yakni (i) Selat Malaka dan Laut Andaman (Pelagis besar $19.61 \%$ dan udang 25.16\%); (ii) Samudera Hindia Sumatera dan Selat Sunda (udang 69\%); (iii) Selat Karimata, Laut Natuna dan Laut Cina Selatan (Pelagis besar $72.06 \%$ dan udang $11.44 \%$ ); (iv) Samudera Hindia selatan Jawa hingga selatan NTT, Laut sawu dan Laut Timor bagian barat (Pelagis besar $9.28 \%$ dan udang 100\%); (v) Laut Jawa (pelagis kecil 14.52\%); (vi) Selat Makasar, teluk Bone dan Laut Flores dan Bali (pelagis besar 5.95\%); (vi) Teluk Tolo dan Laut Banda (Pelagis besar $7.92 \%$, Pelagis kecil $35.22 \%$ dan demersal 162.04\%); (vii) Teluk Tomini, Laut Maluku, Laut Halmahera, laut Seram dan teluk Berau (Pelagis kecil $18.18 \%$ dan udang 8.43\%); (viii) Laut Sulawesi, sebelah utara Halmahera (pelagis kecil 20.29\%); (ix) Teluk Cendrawasi dan Samudera Pasifik (Demersal 9.84\%); dan (x) Teluk Aru, laut Arafura dan Laut Timor bagian utara (Pelagis kecil 16.54\%, dan udang
$34.60 \%$ ). Gambar 1 menyajikan peningkatan stok sumber daya ikan di perairan Indonesia dari tahun 1997-2016 yang mencapai 3.74 ton $(60.42 \%)$.

Stok sumber daya ikan (SDI) dari tahun 20112016 mengalami peningkatan. Peningkatan ini disebabkan oleh: pertama, pemberantasan IUU fishing yang berimbas pada data untuk menghitung SDI semakin baik karena tidak terdapat lagi data yang tidak dilaporkan akibat transhipment di tengah laut dan pencurian oleh kapal asing. Kedua, kebijakan-kebijakan KKP yang melarang alat tangkap yang dilarang (pukat hela dan tarik) dinilai berkontribusi terhadap jaminan proses regenerasi sumber daya ikan secara berkelanjutan. Namun kebijakan ini dalam implementasinya belum berjalan optimal akibat keluarnya Surat Edaran Menteri Kelautan dan Perikanan No. 72 Tahun 2016 yang isinya mengatur pembatasan penggunaan alat tangkap nelayan cantrang di WPPNRI. Pemerintah berpandangan bahwa surat edaran ini sebagai solusi akibat keluarnya Permen KP No. 2 Tahun 2015 yang telah menimbulkan protes nelayan, polemik serta konflik nelayan di beberapa wilayah di Indonesia. Pembatasan ini hanya berlaku di daerah tertentu seperti Jawa Tengah sehingga wilayah perairan lainnya dapat diduga proses regenerasi sumber daya ikan berlangsung secara berkelanjutan. Ketiga, dukungan data yang semakin baik dengan metodologi perhitungan yang lebih akuntabel menyebabkan kesimpulan yang diperoleh mendekati kebenaran.

Produksi perikanan tangkap Indonesia kurun waktu 2014-2018 meningkat dengan kenaikan ratarata $2.82 \%$ per tahun. Total produksi perikanan tangkap tahun 2014 mencapai 6.5 juta ton senilai Rp 108 triliun rupiah meningkat menjadi 7.2 juta ton tahun 2018 senilai Rp 140 triliun. Pencapaian produksi perikanan tangkap tersebut keseluruhannya menggunakan kapal dalam negeri, meskipun diduga $40 \%$ masih ada yang masuk kategori tidak dilaporkan (unreported) (KKP, 2019). Gambar 2 menyajikan produksi perikanan Indonesia 2014-2018.

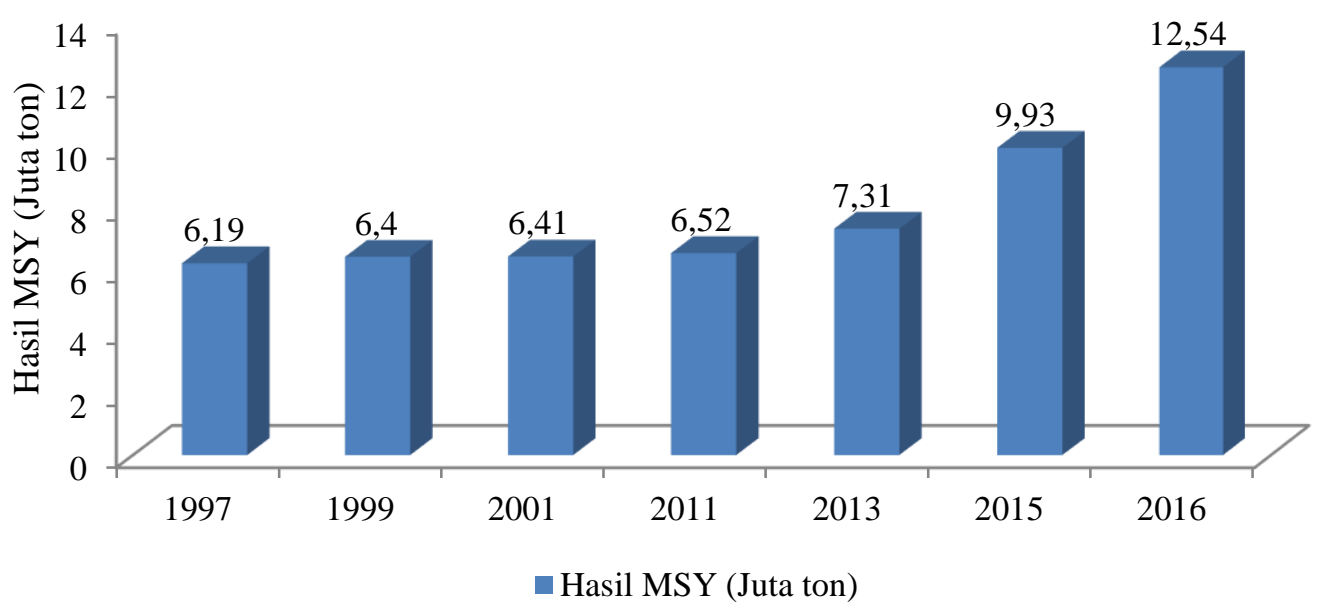

Gambar 1 Peningkatan stok sumber daya ikan di perairan Indonesia.

(Sumber : Pudjiastuti, 2017) 


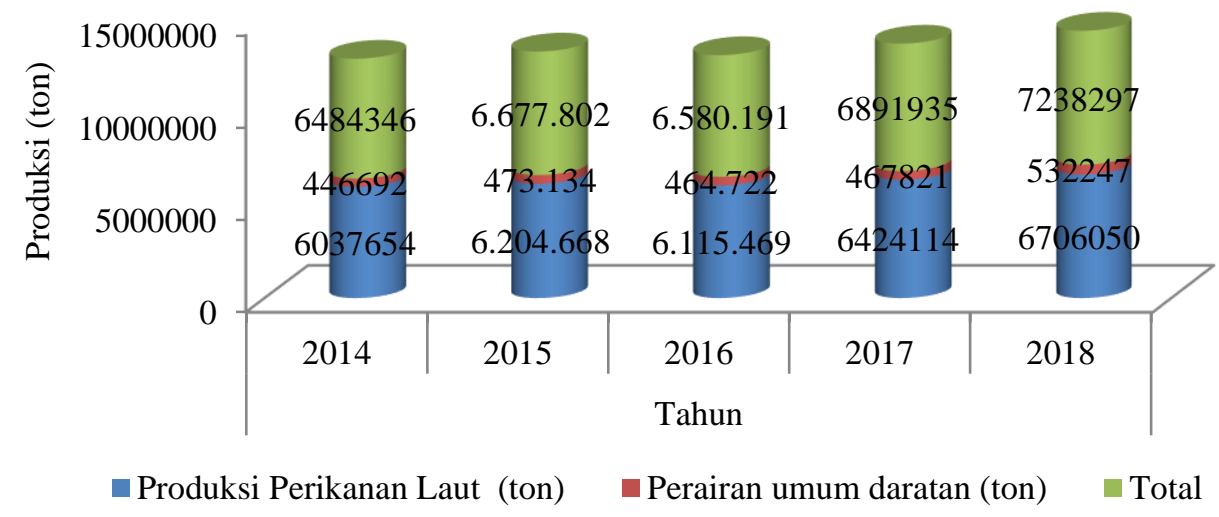

Gambar 2 Produksi perikanan Indonesia 2014-2018.

(Sumber : KKP, 2019)

Di samping itu, konsumsi ikan $\mathrm{kg} / \mathrm{kapita} /$ tahun masyarakat Indonesia juga mengalami peningkatan. Jika tahun 2010 konsumsi ikan per kapita/tahun sebesar $30.48 \mathrm{~kg}$, maka sejak tahun pada tahun 2015-2018 meningkat signifikan yaitu $41.11 \quad \mathrm{~kg} / \mathrm{kapita} / \mathrm{tahun} \quad$ (2015), 43.88 $\mathrm{kg} / \mathrm{kapita} / \mathrm{tahun}$ (2016), $47.12 \mathrm{~kg} / \mathrm{kapita} / \mathrm{tahun}$ (2017) dan $50.65 \mathrm{~kg} / \mathrm{kapita} / \mathrm{tahun}$ (2018).

\section{Kapasitas Terpasang Sumber Daya Ikan}

Laporan survey Bank Indonesia (2015) mencatat bahwa diawal berlakunya kebijakaan KKP memberantas IUU Fishing pasokan bahan baku perikanan cenderung mengalami peningkatan. Pada triwulan tahun IV 2014 nilai pasokan bahan baku ikan mencapai $81.84 \%$. Lalu, memasuki triwulan pertama 2015 pasokannya turun mencapai $61.75 \%$. Pada triwulan II, III dan IV pada tahun 2015 pasokannya meningkat signifikan masing-masing $76.93 \%, 74.44 \%$, dan $74.50 \%$. Pada tahun 2016, dari triwulan I sampai III meningkat dan turun pada triwulan IV. Pada tahun 2017, pada triwulan I dan II naik dan turun kembali pada triwulan III samai IV. Tahun 2018 mulai triwulan I sampai IV meningkat dari $71.15 \%$ menjadi $73 \%$. Peningkatan ini meningkat sampai triwulan I 2019. Lalu pada triwulan II, III dan IV mengalami penuruan. Meskipun kapasitas terpasang ini cenderung fluktuatif nilai rata-ratanya setiap tahun meningkat masing-masing $69.65 \%$ (2015), $71.50 \%$ (2016), $70.99 \%$ (2017), $71.90 \%$ (2018) dan $71.73 \%$ (2019). Dalam kurun waktu 2015-2019 rata-rata kapasitas terpasang sumber daya ikan sebesar $71.36 \%$. Data ini mengkonfirmasi bahwa tuduhan kekurangan pasokan bahan baku industri perikanan di seluruh wilayah Indonesia terbantahkan dan tidak terpengaruh kebijakan pemberantasan kejahatan perikanan. Terkecuali beberapa daerah yang bergantung pasokan bahan baku kapal eks-asing yang dilarang beroperasi di perairan Indonesia dan melakukan alih muatan di tengah laut, misalnya di Bitung Sulawesi Utara.

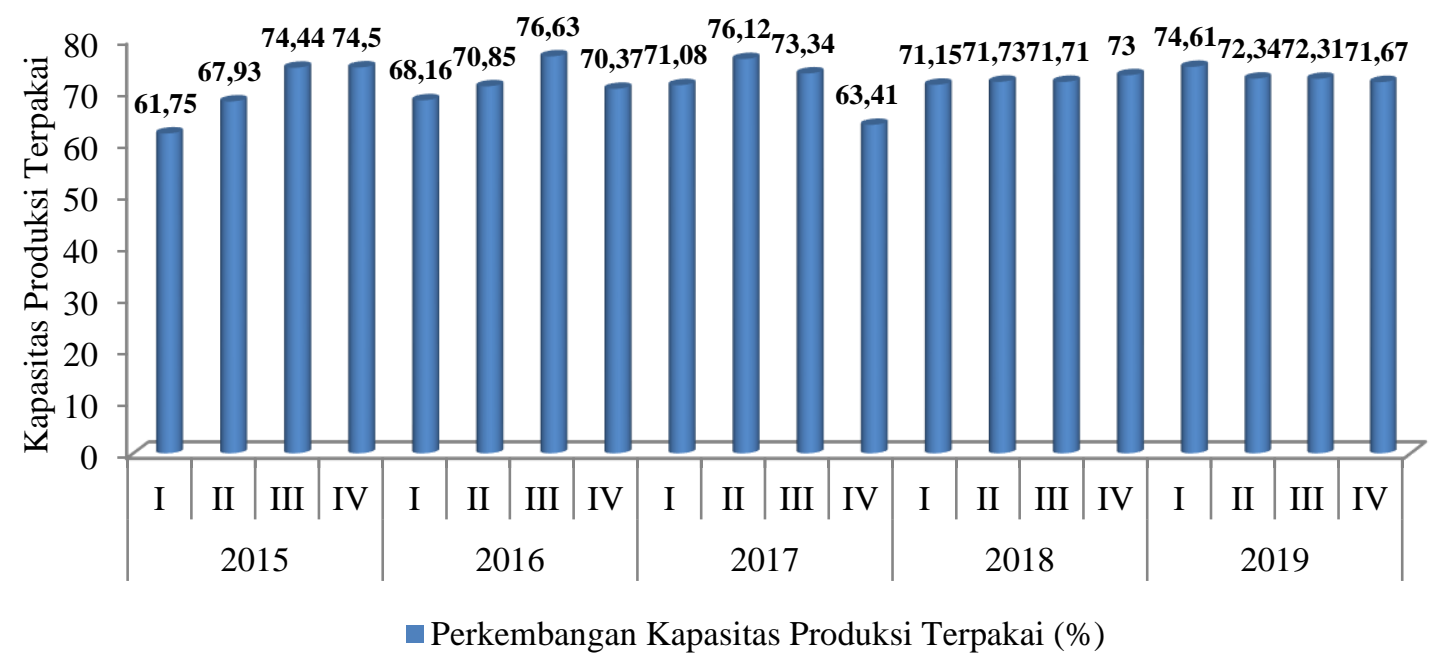

Gambar 3 Perkembangan kapasitas produksi terpakai sektor perikanan (\%). (Sumber : Survei Triwulan IV Bank Indonesia, 2020) 
Dampak kebijakan pemberantasan kejahatan perikanan melalui moratorium terhadap usaha perikanan tangkap di Bitung, Sulawesi Utara dibenarkan oleh hasil penelitian Nurlaili et al., (2016) yang menyatakan bahwa kebijakan moratorium berdampak negatif terhadap usaha perikanan tangkap eks kapal asing yaitu penurunan pendapatan, hilangnya mata pencaharian, berkurangnya bahan baku dalam usaha pengolahan hingga berhentinya produksi ikan olahan, serta berkurangnya ikan yang dipasarkan. Di sisi lain, kebijakan moratorium berdampak positif bagi usaha perikanan tangkap skala kecil yaitu peningkatan produksi, trip melaut, fishing ground dekat, harga ikan meningkat, kemudahan mengakses bahan bakar minyak BBM dan meningkatnya pendapatan. Hal ini pun sejalan dengan hasil penelitian Sianturi (2016) yang menyatakan bahwa kebijakan moratorium efektif dalam memberantas perikanan ilegal di Indonesia.

\section{Neraca Perdagangan dan PDB Sektor Perikanan}

Pada awal kebijakan pemberantasan kejahatan perikanan tahun 2014 ekspor perikanan Indonesia mengalami penurunan. Namun sejak 20152018 ekspor perikanan naik $7.23 \%$ per tahun. Volume ekspor terbesar adalah udang senilai udang (USD 1742.09 miliar atau $7.45 \%$ ) dan rumput laut (213.01 ribu ton atau $11.03 \%$ ). Negara tujuan ekspor terbesar adalah Amerika Serikat (USD 1.88 miliar atau 38.61\%) (KKP, 2019). Tahun 2015-2018, volume neraca perdagangan sektor perikanan mengalami penurunan dari 0.855 juta ton (2015) hingga 0.776 juta ton (2017) dan naik lagi menjadi 0.827 juta ton (2018). Hal ini mengandung arti bahwa pemberantasan kejahatan perikanan berdampak positif terhadap neraca perdagangan sektor perikanan. Membaiknya neraca perdagangan ini berimplikasi pada peningkatan konstribusi PDB sektor perikanan terhadap PDB Nasional. Laporan BPS 2019 mencatat bahwa kontribusinya PDB sektor perikanan terhadap PDB nasional dari tahun 20152018 meningkat drastis dengan rata-rata sebesar $2.56 \%$. Jika diasumsikan setiap kenaikan 1 persen pertumbuhan ekonomi menyediakan lapangan kerja 200000 orang, maka sektor perikanan dapat menyerap sebesar 2.048 juta orang dalam kurun waktu 2015-2018. Sementara, PDB sektor perikanan sendiri dari tahun 2015-2018 mengalami penurunan dari $7.89 \%$ (2015) menjadi 5.20\% (2018), meskipun masih di atas nilai pertumbuhan PDB nasional.

\section{Pendapatan Nasional Bukan Pajak (PNBP) dan Pajak Perikanan}

Komponen lain yang berpengaruh terhadap kebijakan pemberantasan kejahatan perikanan yaitu Penerimaan Negara Bukan Pajak dan pajak perikanan. Gambar 4 menyajikan PNPB dan pajak sektor perikanan yang masuk ke negara selama 20142018. Dalam periode waktu 2014-2018 penerimaan PNBP dan pajak di sektor perikanan mengalami peningkatan. Peningkatan penerimaan pajak sektor perikanan selama 2014-2018 menunjukkan tingginya tingkat kepatuhan pelaku usaha bidang kelautan dan perikanan terhadap aturan hukum dan perpajakan. Hal ini sejalan pula dengan kebijakan KKP dalam mengubah IUU fishing menjadi legal, reported, regulated fishing (LRRF).

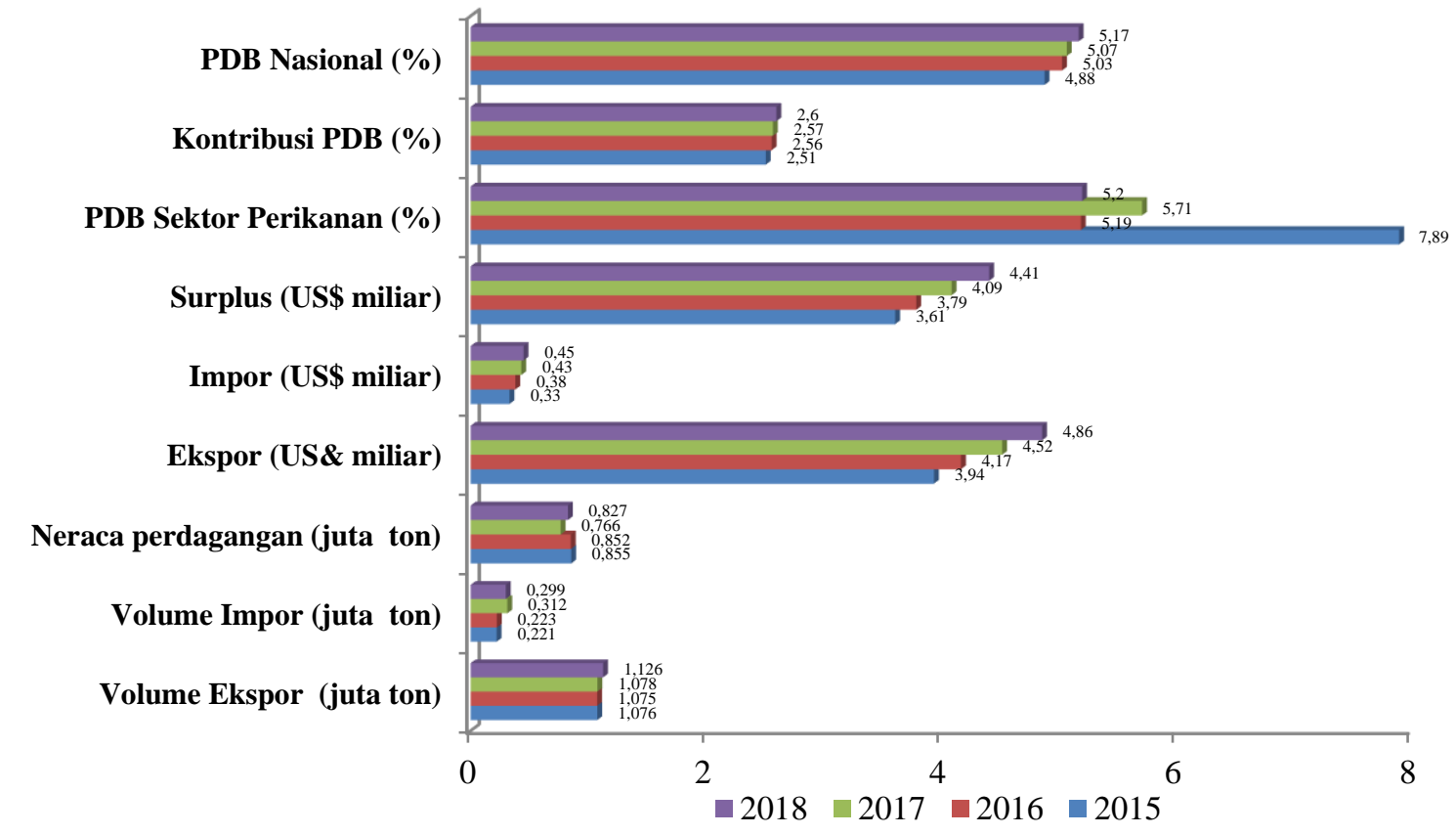

Gambar 4 Neraca perdagangan, konstribusi PDB perikanan terhadap PDB nasional, PDB perikanan dan PDB nasional.

(Sumber : BPS, 2019) 


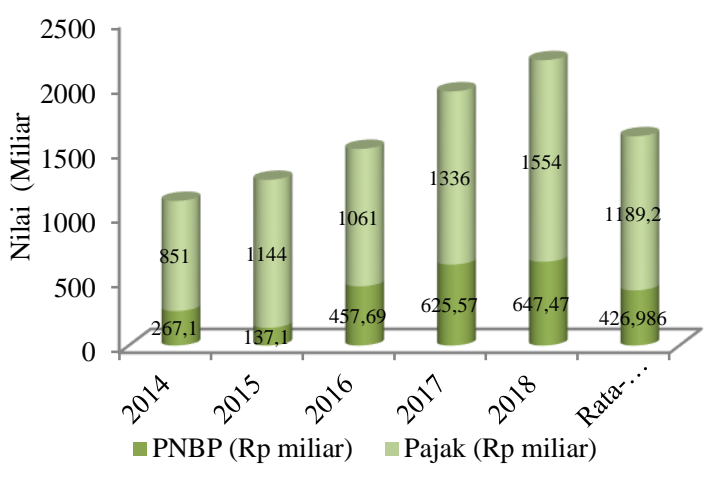

Gambar 5 Penerimaan PNBP dan pajak di sektor perikanan 2014-2018. (Sumber : KKP, 2019)

\section{Nilai Tukar Nelayan (NTN)}

Selama periode 2014-2018 NTN mengalami pertumbuhan rata-rata sebesar $2.01 \%$, dari 104.63 (2014) menjadi 113.28 (2018). Hal ini mengandung arti bahwa daya beli nelayan mengalami perbaikan akibat indeks yang diterima lebih besar dibandingkan indeks yang dikeluarkan. Pasca impelementasi kebijakan pemberantasan kejahatan perikanan mempengaruhi nelayan Indonesia untuk mendapatkan hasil tangkapan. Nelayan lebih mudah mendapatkan akses dalam menangkap ikan yang ditandai oleh waktu yang dibutuhkan untuk melaut menjadi lebih singkat dan penurunan jarak tempuh dalam menemukan ikan yang akan ditangkap. Dengan perkataan lain, kebijakan-kebijakan terkait pelarangan alat tangkap pukat hela dan pukat tarik, moratorium kapal eks-asing, transhipment, dan pengambilan lobster, kepiting bakau dan rajungan dengan ukuran tertentu hingga mengekspor ikan hidup hasil budidaya laut mempengaruhi tingkat kesejahteraan nelayan.

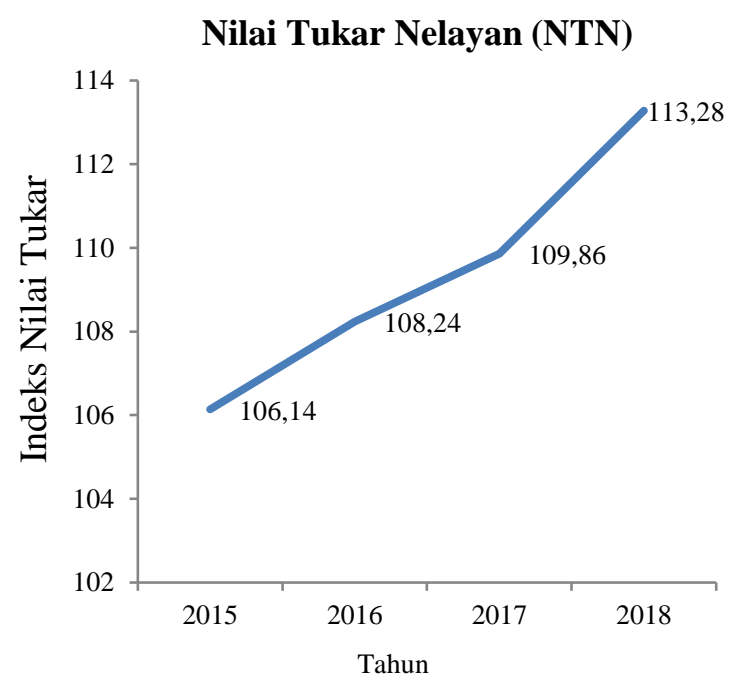

Gambar 6 Nilai tukar nelayan Indonesia 2014-2018.

(Sumber : KKP, 2019)

\section{Konflik Sosial}

Tipologi konflik dalam pengelolaan dan pemanfaatan sumber daya perikanan yaitu (i) negara berhadapan dengan rakyat; (ii) antar negara, dan (iii) antar nelayan atau nelayan dengan non nelayan. Tipologi konflik pengelolaan dan pemanfaatan sumber daya perikanan dalam kajian ini termasuk tipe antar negara berhadapan dengan rakyat, khususnya nelayan yang juga menangkap ikan di wilayah perairan yang sama berhadapan dengan kapal asing dari negara lain dengan teknologi yang lebih maju. Di samping itu, tipologi konflik yang lain yaitu antar nelayan dalam penggunaan teknologi penangkapan ikan yang berbeda seperti yang mengoperasikan kapal trawl dengan nelayan kecil dengan alat tangkap jenis lain (Susilo, 2010). Konflik ini akan mengalami ekskalasi tinggi jika kapal trawl memasuki jalur-jalur penangkapan nelayan skala kecil. Akibatnya terjadi perebutan ruang dan sumber daya ikan sebagaimana yang pernah terjadi di perairan pantai timur Sumatera (Tanjangbalai Asahan), pantai barat Kalimantan Barat hingga Selat Karimata. Konflik ini seringkali memakan korban baik materi maupun non materi seperti kapal-kapal trawl di bakar. Peristiwa yang paling fenomenal dalam kasus pembakaran kapal trawl yang terjadi di pantai timur Sumatera (Tanjungbalai Asahan) pada tahun 2000. Setelah KKP mengeluarkan kebijakankebijakan yang tegas terkait kejahatan IUU Fishing tahun 2014, intensitas konflik antara nelayan pengguna alat tangkap merusak dan nelayan pengguna alat yang ramah lingkungan menjadi relatif berkurang. Walaupun dalam praktiknya, di pantai utara Jawa masih saja terjadi konflik sosial akibat penggunaan alat tangkap yang dilarang seperti cantrang. Hal ini terindikasi pada penolakan kebijakan-kebijakan KKP sehingga menjadi kontra produktif terhadap visi pemerintah yang ingin menjadikan nelayan sebagai "tuan" di rumah sendiri. Merespon aspirasi ini pemerintah memberlakukan pembatasan terbatas pemberlakukan cantrang khususnya di sebagian daerah Jawa Tengah.

Berbagai kejadian konflik perebutan wilayah tangkap yang pernah terjadi di Indonesia sebelum tahun 2006 diantaranya: pantai utara Jawa, Lamongan (1995), Cilincing (10 Juli 2014), Probolinggo (Juli 1995), dan Pasuruan (1995). Sementara, di pulau Sumatera di Nagan Raya (12 Desember 2012), Bagan Asahan (11 Desemner 2011), Tanjung Balai Asahan (6 Januari 2012) dan terakhir Kalimantan Timur tahun 2006 (KKP, 2017). Konflik ini kerap dibarengi tindakan kekerasan lewat pembakaran kapal trawl/cantrang.

\section{Implikasi Kebijakan}

Kebijakan pemberantasan kejahatan perikanan khususnya IUU fishing berimplikasi terhadap perbaikan tatakelola perikanan di Indonesia. Hal ini ditandai oleh salah satunya adalah meningkatnya potensi SDI dari 7.3 juta ton per tahun 
(2015) menjadi 12.54 juta ton per tahun 2016. Selain itu, pemerintah juga telah menerapkan tindakan penegakan hukum secara revolusioner dengan menenggelamkan kapal-kapal pencuri ikan di perairan Indonesia dan ZEEI sebanyak 516 unit kapal sampai Mei 2019 dan melakukan proses hukum. Secara ekonomi politik, kebijakan ini merupakan bentuk keberpihakan dan kehadiran negara untuk menyelamatkan sumber daya ikan, sehingga meningkatkan kesejahteraan dan melindungi nelayan kecil dari perampasan laut yang dilakukan oleh pelaku kejahatan perikanan. Tiga pilar pembangunan kelautan dan perikanan yaitu kedaulatan (sovereignty), kemakmuran (prosperity) dan keberlanjutan (sustainability) yang dijalankan KKP selama 2014-2019 menunjukkan suatu pendekatan yang berbeda dalam manajemen tatakelola perikanan. Bila mengacu pemikiran Gray (2005) yang mengutip Viet \& Dubbink (1999), kebijakan KKP yang diterapkam selama 2014-2018 menerapkannya model tatakelola hierarkis yang sangat berpusat pada negara (state centries). Dengan perkataan lain tatakelola sumber daya perikanan bersifat direktif (directive) yang mengedepankan aturan main yang dibuat negara. Model tatakelola perikanan semacam ini bersifat top-down yang lebih menekankan legalitas, legitimasi politik, sentralistik, birokratis, intervesionis, bersifat komando dan kontrol, serta elitis secara ilmiah (scientific elitism) dan eksklusif yang peka terhadap pertanggungjawaban publik. Model ini dibangun dengan idiologi yang bersifat "administrative rationalism" yaitu kebijakan penyusunan tatakelola perikanan dipercayakan kepada para ahli perikanan (leave it to the expert).

Model tatakelola ini berimplikasi terhadap (i) Aktivitas pencurian ikan oleh kapal perikanan ilegal mengalamai penurunan drastis, akibat kebijakan radikal melalui tindakan penggelaman yang mencapai 5016 unit kapal hingga 2019; (ii) stok sumber daya ikan (SDI) mengalami peningkatan mencapai 12.54 juta ton pada tahun 2016; (iii) produksi perikanan dan konsumsi ikan per kapita masyarakat Indonesia dari tahun 2014-2018 meningkat; (iv) kapasitas terpasang sumber daya ikan dalam kurun waktu 2015-2019 terjamin terkecuali ada beberapa kasus seperti di wilayah Bitung, Sulawesi Utara. Penyebabnya ialah ketergantungan pada kapal eks-asing yang banyak dicabut izinnya karena menyalahi aturan yang berlaku; (v) Neraca perdagangan dan PDB sektor perikanan terhadap PDB nasional mengalami peningkatan disertai perdagangan komoditas perikanan dari tahun 2015-2018. Meskipun pada tahun 2015, perdagangan ikan ke Jepang ditemukan kasus impor ilegal (Ganapathiraju et al., 2017); (vi) PNBP dan pajak sektor perikanan meningkat secara signifikan terutama dari tahun 2014-2018; (vii) Secara nasional, nilai tukar nelayan (NTN) sebagai indikator mengukur kesejahteraan nelayan dalam periode 2014-2018 juga mengalami peningkatan.
Selama penerapan kebijakan pemberantasan kejahatan perikanan dalam periode 2014-2018, konflik dalam pengelolaan dan pemanfaatan sumber daya perikanan belum tuntas sepenuhnya, namun eskalasinya semakin menurut dan penyebabnya menjadi beragam. Oleh karena itu, kebijakan selanjutnya sejatinya tidak hanya memperbaiki keberlanjutan stok sumber daya ikan, meningkatkan manfaat ekonominya, melainkan juga dapat menuntaskan konflik yang terjadi dengan resolusi yang tepat sehingga pengelolaan dan pemanfaatan sumber daya perikanan dapat mensejahterakan seluruh rakyat.

\section{Rekomendasi}

Kejahatan perikanan di perairan Indonesia sejak dulu kerapkali memakan korban baik itu nelayan kecil maupun pemilik kapal ikan akibat berebut akses dan ruang sumber daya. Pihak yang terlibat yaitu: pertama, antara nelayan domestik dengan kapal asing yang mencuri ikan di perairan ZEEI. Kedua, nelayan kecil/masyarakat adat dengan pengusaha perikanan yang mengoperasikan kapal dengan alat tangkap yang merusak hingga menyerobot perairan perikanan skala kecil. Ketiga, pengusaha perikanan domestik yang mengoperasikan kapal eks-asing dengan nelayan kecil/tradisional. Namun, penyelesaiannya terhadap kasus yang menimpa korban seringkali tidak tuntas, dan memakan waktu lama dalam proses hukumnya. Proses hukum ini sebetulnya telah diatur sejak berlakunya UU Perikanan No. 31 Tahun 2014 yang di dalamnya dapat menyelenggarakan peradilan perikanan, walaupun dalam praktiknya belum optimal. Proses hukum yang sudah selesai seringkali masyarakat yang terkena dampak kerugian tidak memperoleh kompensasi dan negara pun tidak mendapatkan manfaat. Akibatnya, kebijakan pemberantasan kejahatan perikanan belum sepenuhnya memberi efek jera sampai saat ini. Setiap tahun pasti ada aktivitas IUU fishing di Indonesia. Kejadian awal tahun 2020 yaitu masuknya kapal ikan Cina dan Vietnam yang mencuri ikan di perairan ZEEI Laut Natuna Utara dan dikawal kapal penjaga pantainya jadi bukti empirisnya. Berkaitan dengan hasil kajian ini penulis merekomendasikan perlunya mempertimbangkan penerapan model keadilan restoratif (restorative justice) untuk menangani proses hukum kejahatan perikanan sebagai model alternatif pilihan tatakelola perikanan selain proses pengadilan perikanan yang amanatkan UU Perikanan No. 31 Tahun 2014 dan revisinya No. 45 Tahun 2009. van Ness \& Strong (2010) mendefinisikan keadilan restoratif sebagai teori keadilan yang menekankan penyelesaian masalah dengan menangani kerugian yang disebabkan perilaku kriminal. Proses terbaik untuk mencapainya adalah melalui kerjasama (cooperative) yang melibatkan semua pemangku kepentingan (stakeholders). Meskipun awalnya konsep ini diterapkan dalam bidang kejahatan non sumber daya alam dan lingkungan seperti narkoba, 
dan pelanggaran HAM. Namun, penerapan dalam perselisihan lingkungan berhasil diterapkan Cina sejak tahun 1950-an untuk menyelesaikan ratusan ribu kasus perselisihan lingkungan yang dinamai pendekatan non litigasi (Zhang, 2017) dan juga di Kanada dalam mengatasi kejahatan perikanan yang merugikan masyarakat adat Mi'kmaq (Chartrand \& Horn 2016). Ufran \& D'Amaral (2019) menyatakan bahwa keadilan restoratif merupakan cara penanganan kejahatan yang menyeimbangkan kebutuhan masyarakat, korban dan pelaku, sehingga penyelesainnya bersifat holistik karena berupaya memahami kejahatan dan mengatasi dinamika perilaku kriminal, penyebab dan konsekuensinya. Dalam kasus lingkungan penerapan model keadilan restoratif bersifat transformatif bagi korban, pelaku, masyarakat, lingkungan dan sistem peradilan pidana sehingga hasilnya lebih adil karena korban akan mendapatkan reparasi, restitusi dan kompensasi akibat kerusakan lingkungan, termasuk dalam kejahatan perikanan.

Konsep ini mirip dengan pemikiran Thang (2017) dalam perikanan yang mengkritik pemikiran Elinor Ostrom yang dianggapnya terlalu bias masyarakat dan bersifat polisentrik yang mengabaikan peran negara dalam tatakelola perikanan. Kritik ini dibangun berdasarkan penelitiannya pada tiga lokasi yang berbeda yang juga mempraktikan co-management dalam pengelolaan common pool resources (CPLs), yaitu Norwegia, Jepang dan Vietnam dengan karakterisitik khasnya masing-masing. Thang menuangkan secara lengkap hasil penelitiannya itu dalam buku yang judul "Rethingking Fisheries Governance, The Role of States and Meta-Governance". Thang tetap menyepakati co-manajemen dalam tatakelola perikanan, tetapi untuk menyeimbangkan dengan peran negara ia mengajukan konsep MetaGovernance. Dalam meta-governance tersebut Thang mengusulkan lima tipe fungsinya yaitu: pertama, menjamin bahwa semua tujuan strategis manajemen perikanan terpenuhi yakni penentuan tujuan, mekanisme koordinasi, dan kontrol aransemen tatakelola yang bersifat spesifik (steering). Kedua, memonitoring performa tindakan yang kurang berhasil terkait kelayakan atau tidaknya aransemen tatakelola perikanan (effective). Ketiga, adanya kepemimpinan dan otoritas dalam tatakelola sumber daya ikan, kebijakan fiskal maupun administrasi, partisipasi pakar kebijakan secara totalitas, ketersediaan sarana informasi yang mampu menyebar luaskan hukum berbentuk aturan maupuan norma. Keempat, terpenuhinya praktik dan norma demokrasi. Kelima, adanya batasan yang jelas terkait tanggung jawab untuk menciptakan akuntabilitas yang kuat. Keenam, adanya legitimasi politik sehingga diterima secara demokratis dan akuntabel.

Belajar dari pengalaman Cina dan Kanada mengatasi perselisihan lingkungan dan perikanan serta pemikiran Thang soal tatakelola perikanan terbaru, maka penerapan keadilan restoratif dalam menangani kasus kejahatan perikanan tanpa harus melewati pengadilan pidana sangat memungkinkan. Konsepnya pun tak menyalahi "hak menguasai negara" dalam Pasal 33 UUD 1945 dan UU Pokok Agraria No. 5 Tahun 1960. Maknanya, negara tetap menguasai sumber daya ikan di wilayah NKRI. Asalkan, negara juga mau mengakui hak masyarakat (nelayan, masyarakat adat) yang menggantungkan hidupnya pada sumber daya ikan. Problemnya, selama ini masyarakat yang menggantungkan hidupnya pada perikanan menjadi "korban" akibat kejahatan perikanan yang sudah berlangsung lima dekade semenjak modernisasi perikanan 1970-an. Prasyaratnya, negara mesti mengakui hak kepemilikan masyarakat (co-ownership) atas sumber daya ikan baik secara komunal/komunitas maupun kelompok masyarakat pesisir hingga asosiasi nelayan. Di Indonesia memang ada ketentuan tentang jalur-jalur penangkapan ikan, tetapi tak memberikan kepastian hak kepemilikan nelayan kecil maupun masyarakat adat. Aturan ini hanya mengatur batasan wilayah tangkap berdasarkan ukuran kapal dan alat tangkapnya (Permen KP No. 71 Tahun 2016). Penerapan model keadilan restoratif ini sebagai alternatif untuk dipertimbangkan dalam menangani kejahatan perikanan agar dapat memulihkan sumber daya ikan dan penggantian kerugian yang dialami masyarakat (nelayan, masyarakat pesisir/adat) dan sekaligus memerankan mereka untuk mengawasi dan melaporkannya jika ada tindakan kejahatan perikanan yang dilakukan oleh masyarakat lokal atau kapal asing. Peran negara dalam mekanisme ini yaitu memediasi dan memfasilitasi penyelesaian kerugian akibat kejahatan perikanan baik yang dilakukan kapal asing, korporasi domestik maupun nelayan lain yang menggunakan alat tangkap tak ramah lingkungan (semacam trawl). Negara juga bisa mengkonsolidasikan dan membangun kerjasama sama secara regional dan global untuk memasukkan kejahatan perikanan sebagai kejahatan transnasional dan menjadikaan tindakan pemberantasannya sebagai agenda bersama negara-negara yang memiliki sumber daya ikan. Hal ini dikarenakan perusahaan negara yang mencuri ikan di suatu negara selama ini sulit mengganti kerugian negara dan masyarakat yang mengalaminya, sehingga kerjasama antar negara akan memudahkan proses hukum pengadilan maupun memediasi mekanisme keadilan restoratif.

\section{SIMPULAN}

Hasil penelitian ini disimpulkan bahwa kebijakan pemberantasan kejahatan perikanan di Indonesia selama kurun waktu 2014-2018 belum berjalan secara optimal. Penyebabnya pada tataran implementasi menimbulkan resistensi khususnya dari nelayan cantrang di Jawa Tengah, sehingga pemerintah memberlakukan pemberlakuan terbatas di daerah tersebut. Pemberantasan kejahatan perikanan di Indonesia secara menyeluruh 
berimplikasi terhadap perbaikan dan keberlanjutan sumber daya ikan dan perbaikan kesejahteraan nelayan. Hal ini ditandai oleh beberapa indikator diantaranya: perbaikan stok sumber daya ikan secara lestari, produksi perikanan Indonesia, kapasitas terpasang sumber daya ikan, neraca perdagangan dan PDB sektor perikanan, penerimaan PNBP dan pajak, nilai tukar nelayan, hingga ekskalasi konflik sosial relatif berkurang di masyarakat nelayan.

Namun, selama periode itu kejahatan perikanan masih tetap terjadi yang ditandai adanya pencurian oleh kapal asing, perdagangan ikan ilegal ke Jepang dan kekurangan bahan baku industri perikanan di beberapa daerah akibat ketergantungan terhadap hasil tangkapan dari kapal eks-asing dan kapal asing yang dilarang pemerintah. Kebijakan pemberantasan kejahatan perikanan harus tetap dilanjutkan agar sumber daya perikanan Indonesia terjaga dan terlindungi sehingga berdaulat atas perairannya.

Penanganan kasus kejahatan perikanan tak selamanya harus dilakukan dengan mekanisme pengadilan perikanan semata melainkan bisa melalui non pengadilan yaitu mekanisme keadilan restoratif (restorative justice) yang membebankan pelaku kejahatan untuk mengganti kerugian dan pemulihan sumber daya ikan akibat tindakan kejahatannya. Hal ini berhasil dipraktikan di Cina dalam kasus penanganan lingkungan dan perikanan di Kanada. Penerapan kebijakan ini akan lebih efektif jika Indonesia membangun kerjasama regional dan global untuk menerapkan model keadilan restoratif karena para penggusaha pemilik kapal pelaku kejahatan perikanan bersifat regional dan global.

\section{DAFTAR PUSTAKA}

Agnew DJ, Pearce J, Pramod G, Petaman T, Waston R, Beddington JR \& Pitcher TJ. (2009). Estimating the Worldwide Extent of Illegal Fishing. PloSone Journal, 4, (2), 1-8.

Arthatiani FY \& Apriliani T. (2015). Dampak Kebijakan Moratorium Kapal Eks Asing terhadap Kondisi Perikanan Tuna: Studi Kasus di DKI Jakarta. Jurnal Kebijakan Sosial Ekonomi Kelautan dan Perikanan, 5, (2), 71-82.

[BI] Bank Indonesia. 2015. Survei Kegiatan Dunia Usaha. Triwulan I 2015. Jakarta: BI. Diacu pada 20 Januari 2020 dari: https://www.bi. go.id/id/publikasi/survei/kegiatan-duniausaha/Default.aspx.

[BI] Bank Indonesia. 2020. Survei Kegiatan Dunia Usaha. Triwulan IV 2019. Jakarta: BI. Diacu pada 20 Januari 2020 dari: https://www.bi .go.id/id/publikasi/survei/kegiatan-duniausaha/Default. aspx.

Bennet NJ, Govan H \& Satterfield T. (2015). Ocean Grabbing, Marine Policy Journal, 57, 61-68.

[BPS] Badan Pusat Statistik. (2019). Laporan Perekonomian Indonesia 2019. Jakarta: BPS.
Cabral RB, Mayorga J, Clemence M, Lynham J, Koeshendrajana S, Muawanah U, Nugroho D, Anna Z, Mira, Ghofar A, Zulbainarni N, Gaines SD \& Costello C. (2018). Rapid and Lating Gains from Solving Illegal Fishing. Nature Ecology \& Evolution Journal, 650, (2), 650-658.

Chartrand L \& Horn K. 2016. A Report on the Relationship between Restorative Justice and Indigenous Legal Traditions in Canada. Ottawa: The Department of Justice Canada. Diacu pada 8 Februari 2020 dari: https://www.justice.gc.ca/eng/rp-pr/jr/rjiltjrtja/index.html.

Dunn WN. (2013). Pengantar Analisis Kebijakan Publik. (Edisi Kedua). Yogyakarta: Gajah Mada University Press.

Ewell C, Suzuki SC, Ediger M, Hocevar J, Miler D \& Jacquet J. (2017). Potential ecological and social benefits of a moratorium on transshipment on the high seas. Marine Policy Journal, 81, 293-300.

Firdaus M, Dewitasari Y, Pramoda R \& Koeshendrajana S. (2017). Kerugian Sumber Daya Ikan Akibat Praktik Mardown Kapal Penangkap Ikan di Indonesia. Jurnal Sosial Ekonomi Kelautan dan Perikanan, 12, (2), 133-141.

Ganapathiraju P, Pitcher TJ \& Mantha G. (2017). Estimates of illegal and unreported seafood imports to Japan. Marine Policy Journal, 84, $42-51$.

Gray ST. (2005). Participation in Fisheries Governance. Reviews Methods and Technologies Fish Biology and Fisheries. USA: Springer.

Hikmayani Y, Rahardian R, Nurlaili \& Muhartono R. (2015). Efektivitas Pemberlakukan Kebijakan Moratorium Kapal Eks Asing dan Transhipment terhadap Kinerja Usaha Penangkapan ikan. Jurnal Kebijakan Sosial Ekonomi Kelautan dan Perikanan, 5, (2), 100112.

[KKP] Kementrian Kelautan dan Perikanan. (2019). Laporan Tahunan 2018. Jakarta: KKP.

[KKP] Kementrian Kelautan dan Perikanan. (2017). Analisis Kebijakan Pelarangan Cantrang. Jakarta: KKP.

[KKP] Kementrian Kelautan dan Perikanan. (2016). Keputuan Menteri Kelautan dan Perikanan Republik Indonesia Nomor 47/KEPMENKP/2016 tentang Estimasi Potensi, Jumlah Tangkapan yang Diperbolehkan, dan Tingkat Pemanafaatan Sumber Daya Ikan di Wilayah Pengelolaan Perikanan Negara Republik Indonesia. Jakarta: KKP.

[KKP] Kementrian Kelautan dan Perikanan. (2016). Peraturan Menteri Kelautan dan Perikanan Republik Indonesia Nomor 71/PERMENKP/2016 tentang Jalur Penangkapan Ikan dan Penempatan Alat Penangkapan Ikan di 
wilayah Pengelolaan Perikanan Negara Republik Indonesia. Jakarta: KKP.

[KKP] Kementrian Kelautan dan Perikanan. (2016). Potensi Dan Tingkat Pemanfaatan Sumberdaya Ikan Di Wilayah Pengelolaan Perikanan Republik Indonesia (WPP RI). Jakarta: KKP.

[KKP] Kementrian Kelautan dan Perikanan. (2016). Peraturan Menteri Kelautan Perikanan No. 15/2016 tentang Kapal Pengangkut Ikan Hidup. Jakarta: KKP.

[KKP] Kementrian Kelautan Perikanan. (2015). Peraturan Menteri Kelautan Perikanan No. 1/2015 tentang Larangan Penangkapan Lobster, Kepting dan Rajungan. Jakarta: KKP.

[KKP] Kementrian Kelautan Perikanan. (2015). Peraturan Menteri Kelautan dan Perikanan No 2/ PERMEN-KP/2015 tentang Larangan Penggunaan Alat Penangkapan Ikan Pukat Hela (Trawls) dan Pukat Tarik (Seine Nets) di wilayah Pengelolaan Perikanan Negara Republik Indonesia. Jakarta: KKP.

[KKP] Kementrian Kelautan Perikanan. (2015). Peraturan Menteri Kelautan dan Perikanan No 10/ PERMEN-KP/2015 tentang Perubahan atas Peraturan Menteri Kelautan dan Perikanan No 56/ PERMEN-KP/2014 tentang Penghentian Sementara (Moratorium) Perizinan Usaha Perikanan Tangkap di Wilayah Pengelolaan Perikanan Negara Republik Indonesia. Jakarta: KKP.

[KKP] Kementrian Kelautan Perikanan. (2015). Peraturan Menteri Kelautan dan Perikanan No 35/ PERMEN-KP/2015 tentang Sistem dan Sertifikasi Hak Asasi Manusia pada Usaha Perikanan. Jakarta: KKP.

[KKP] Kementrian Kelautan Perikanan. (2014). Peraturan Menteri Kelautan dan Perikanan Republik Indonesia No 57/ PERMENKP/2014 tentang Perubahan Kedua Peraturan atas Peraturan Menteri Kelautan dan Perikanan No 30/MEN/2012 tentang Usaha Perikanan Tangkap di Wilayah Pengelolaan Perikanan Negara Republik Indonesia. Jakarta: KKP.

[KKP] Kementrian Kelautan Perikanan. (2014). Peraturan Menteri Kelautan dan Perikanan Republik Indonesia No 49/ PERMENKP/2014 tentang Usaha Budidaya Ikan. Jakarta: KKP.

Kasim N \& Widagdo A. (2019). Combating illegal, unreported, unregulated (IUU) fishing in Indonesia. AACL Bioflux, 12, (6), 2243-2251.

Kondo NS, Keban YT, Rijanta \& Mulyo JH. (2019). Dampak Sosioekonomi Moratorium izin Penangkapan Ikan dan Larangan Transhipment di Kota Bitung. Journal of Marine Fisheries, 10, (1), 71-82.

Nurlaili, Muhartono R \& Hikmayani Y. (2016). Dampak Kebijakan Moratorium Terhadap
Sektor usaha Perikanan Tangkap di Kota Bitung. Jurnal Kebijakan Sosial Ekonomi, 6, (2), 145-152.

Pemerintah Indonesia. (1960). Undang-Undang Republik Indonesia Nomor 5 Tahun 1960 tentang Peraturan Dasar Pokok-Pokok Agraria. Jakarta: Sekretariat Negara RI.

Pemerintah Indonesia. (1980). Keputusan Presiden Republik Indonesia Nomor 39 Tahun 1980 tentang Penghapusan Jaring Trawl. Jakarta: Sekretariat Negara RI.

Pemerintah Indonesia. (2009). Undang-Undang Republik Indonesia Nomor 45 Tahun 2009 tentang Perubahan Atas Undang-Undang Nomo 31 Tahun 2004 Tentang Perikanan. Jakarta: Kementrian Hukum dan Hak Asasi Manusia.

Pemerintah Indonesia. (2015). Peraturan Presiden Nomor 115 Tahun 2015 tentang Satuan Tugas Pemberantasan Penangkapan Ikan secara Ilegal (Illegal Fsihing). Jakarta: Sekretariat Kabinet RI.

Puspoayu ES, Sari CY \& Ramadhan VC. (2019). Praktik Illegal Transshipment di Laut lepas Berdasarkan Hukum Laut Internasional. Jurnal MIMBAR HUKUM, 31, (1), 75-94.

Pudjiastuti S. (2016). Pemberantasan Illegal, Unreported and Unregulated (IUU) Fishing: Menegakkan Kedaulatan dan Menjaga Keberlanjutan untuk Kesejahteraan Bangsa Indonesia. Disampaikan dalam Penganugerahan Doktor Honoris Causa (Dr HC) di Kampus Universitas Diponegoro (UNDIP) Semarang.

Sianturi SPIM. (2016) Efektifitas Kebijakan Moratorium Kapal Eks Asing Terhadap Tindakan Illegal Fishing di Perairan Indonesia. Periode 2014-2015. Journal of International Relations, 2, (4), 50-58.

Sugiyono. (2012). Metode Penelitian Kuantitatif Kualitatif dan R\&D. Bandung: Alfabeta.

Susilo E. (2010). Dinamika Struktur Sosial Dalam Ekosistem Pesisir. Malang: UB Press.

Thang HV. (2017). Rethingking Fisheries Governance. The Role of States and MetaGovernance. London: Palgrave Macmillan.

Telesetsky A. (2015). Laundering Fish in the Global Undercurrents: Illegal, Unreported, and Unregulated Fishing and Transnational Organized Crime. Ecology Law Quarterly, 41, (4).

Thurstan RH, Brockington S \& Roberts CM. (2010). The effects of 118 years of industrial fishing on UK bottom trawl fisheries. NATURE COMMUNICATIONS Journal, 1, (15), 1-6.

Ufran \& D'Amaral A. (2019). Initiating the Utilization of Restorative Justive in Completing of the Environmental Crime Cases. Jurnal Hukum \& Pembangunan, 49, (3), 671-687. 
[UNDOC] United Nations Office on Drugs and Crime. (2011). Transnational Organized Crime in the Fsihing Industry. Focus on: Trafficking in Persons Smuggling of Migrants Illicit Drugs Trafficking. Vienna: United Nations.

van Ness DW \& Strong KH. (2010). Restoring Justice: An Introduction to Restorative Justice. Fourth Edition. Texas: Anderson Publishing \& LexisNexis Group.

Varkey D, Ainsworth CH, Pitcher TJ, Goram Y \& Sumaila R. (2010). Illegal, unreported and unregulated fisheries catch in Raja Ampat Regency, Eastern Indonesia. Marine Policy Journal, 34, 228-236.

Widodo AA \& Suryanto. (2015). Analisis Dampak Pelarangan Alih Muatan (Transshipment) Ikan Hasil Tangkapan pada Armada Pukat Cincin Pelagis Besar. (Studi kasus pada perikanan pukat cincin pelagis besar di WPP NRI 716-717 berbasis di Bitung). Jurnal Kebijakan Perikan.Indonesia, 7, (2), 93-102

World Bank. (2017). Thailand Economic Monitor 2017. Digital Transformation. Bangkok: World Bank Office.

Zhang Shijun. (2017). The Non-litigation Approach to Environmental Disputes in China: The Environmental Complaint Letters and Visits System-An Analysis in Environmental Policy and Governance in China, Kitagawa (ed.). Tokyo: Springer. 